\title{
Inhibiting IL-6 During Cytokine Storm in COVID-19: Potential Role of Natural Products
}

\section{Running title: Inhibiting IL-6 During Cytokine Storm in COVID-19}

\author{
Amirreza Nasirzadeh ${ }^{1}$, Mohammad hosein Jafarzadeh Maivan², Javad Bazeli ${ }^{2}$, Jafar Hajavi ${ }^{3}$, Negar \\ Yavarmanesh ${ }^{4}$, Mohammad Zahedi $^{5}$, Mahdi Abounoori ${ }^{6}$, Alireza Razavi ${ }^{6}$, Mohammad Moein \\ Maddah $^{6}$, Parham Mortazavi ${ }^{7}$, Mohammad Moradi $^{8}$, Siamak Heidarzadeh ${ }^{9}$, Jalal Mardaneh ${ }^{10^{*}}$, Afshin \\ Shoeibi $^{11,12}$, Roohallah Alizadehsani ${ }^{13}$, Sheikh Mohammed Shariful Islam ${ }^{14,15,16}$ \\ ${ }^{1}$ Student Research Committee, Nursing Department, Nursing and Midwifery, Mashhad University of Medical \\ Sciences, Mashhad, Iran. \\ ${ }^{2}$ Student Research Committee, Gonabad University of Medical Sciences, Gonabad, Iran. \\ ${ }^{3}$ Department of Immunology, School of Medicine, Gonabad University of Medical Sciences, Gonabad, Iran. \\ ${ }^{4}$ Student Research Committee, School of Pharmacy; Mashhad University of Medical Sciences, Mashhad, Iran. \\ 5 Department of Laboratory Sciences, School of Allied Medical Science, Student Research Committee, \\ Mazandaran University of Medical Sciences, Sari, Iran. \\ ${ }^{6}$ Medical Student, Student Research committee, Mazandaran University of Medical Sciences, Sari, Iran. \\ ${ }^{7}$ Student Research Committee, School of Pharmacy, Mazandaran University of Medical Sciences, Sari, Iran. \\ ${ }^{8}$ Resident of General Surgery, Iran University of Medical Sciences, Tehran, Iran. \\ ${ }^{9}$ Zanjan University of Medical Sciences, Zanjan, Iran. \\ ${ }^{10}$ Department of Microbiology, School of Medicine, Infectious Diseases Research Center, Gonabad University \\ of Medical Sciences, Gonabad, Iran. \\ ${ }^{11}$ Faculty of Electrical and Computer Engineering, Biomedical Data Acquisition Lab, K. N. Toosi University of \\ Technology, Tehran, Iran \\ ${ }^{12}$ Department of Computer Engineering, Ferdowsi University of Mashhad, Mashhad, Iran \\ ${ }^{13}$ Institute for Intelligent Systems Research and Innovation (IISRI), Deakin University, Victoria, Australia \\ ${ }^{14}$ Institute for Physical Activity and Nutrition, Deakin University, Melbourne, Australia \\ ${ }^{15}$ Cardiovascular Division, The George Institute for Global Health, Australia \\ ${ }^{16}$ Sydney Medical School, University of Sydney, Australia
}

Corresponding author: Jalal Mardaneh, Department of Microbiology, School of Medicine, Infectious Diseases Research Center, Gonabad University of Medical Sciences, Gonabad, Iran. Email: Jalalmardaneh@yahoo.com

\begin{abstract}
Plant species with anti-inflammatory properties might play an essential role in combatting COVID-19 via reducing cytokine storms. We aimed to review the extant evidence of the potential therapeutic efficacy of natural products against cytokine storms by inhibiting interleukin-6 (IL-6) as a major pathological mediator. Data were collected following an electronic search in major databases (Pubmed, Scopus, Web of Science, Google Scholar) and also preprint articles on preprint and medRxiv servers by using a combination of relevant keywords. Seventeen active compounds and medicinal plants were found and reviewed in the present review. Results of both in-vivo and in-vitro experiments conducted on these compounds showed that Phillyrin, SMFM, Qiangzhi decoction, curcumin, Shen-Fu, Forsythia, and Alpha-Mangostin inhibit the production of IL-6. Andrographolide
\end{abstract}


and Liu Shen Wan have an inhibitory effect on releasing this agent, while Ilex Asprella and Deoxy11,12-didehydroandrographolide and naringin reduce the expression of IL-6. Theaflavin and Cholorogenic acid inhibit the secretion of IL-6, Xuebijing, and Chai-Hu-Gui-Zi-Gan-Jiang-Tang and Lipanpaidu prescription can reduce the serum level of IL-6. These agents also effectively improve infected lungs, increase survival rates, and minimize tissue damage. Medicinal plants and their phytochemical ingredients with down-regulatory effects on the expression of IL-6 have a potential influence on the inhibition of cytokine storms during viral infection caused by COVID-19. Therefore, phytochemicals could be regarded as promising candidates for managing cytokine storm inflammatory responses due to COVID-19 infection.

Keywords: COVID-19; Cytokine storm; IL-6; Natural product.

\section{Introduction}

\subsection{COVID-19 general features, nominating, and taxonomy}

At the end of 2019, the outbreak of a new member of the coronaviridae family, causing a severe respiratory disease, was reported in Wuhan, Hubei, China. Later, the disease was called the Corona Virus Disease 2019 (COVID-19) (Ayoobi et al., 2021; Ghassemi et al., 2021; Prompetchara, Ketloy, \& Palaga, 2020; Shoeibi et al., 2020). The COVID-19 disease is caused by the severe acute respiratory syndrome-associated coronavirus (SARS-CoV-2), which phylogenetically, forms a sister clade with its prototype in humans and bats (Alizadehsani, Alizadeh Sani, et al., 2021; Eskandarian et al., 2021; Gorbalenya, 2020; Sharifrazi et al., 2021).

The causative agent of COVID-19 belongs to the Coronaviridae family. The name of this family is because of the presence of the projections resembling a solar corona in electron microscopy images on the virus's surface (Vankadari \& Wilce, 2020). Coronaviruses are enveloped viruses containing a 26$32 \mathrm{~kb}$ single-stranded sense RNA, encoding the particles arranging as large ( $20 \mathrm{~nm})$, petal- or clubshaped surface projections (the "spikes" or "peplomers"). These spherical particles are visualized as solar corona in electron microscopy images (Alizadehsani, Sharifrazi, et al., 2021; Fehr \& Perlman, 2015).

Coronaviruses have been recognized in a variety of avian hosts and mammals. These viruses have been responsible for many diseases from the common cold to more severe conditions such as SARSCoV, MERS-CoV, and most recently, the COVID-19. The virus causing COVID-19 resembles (over $79 \%$ similarity in genome sequence) the virus strain causing SARS-CoV; however, it shows lower homology $(50 \%)$ to MERS-CoV. Three common structural membrane proteins of SARS-Cov-2 include the spike (S), membrane protein (M), and small membrane protein (E). Furthermore, nearly all coronaviruses have four functional proteins, including papain-like protease (PLpro), 3- 
chymotrypsin-like protease (3CLpro), RNA-dependent RNA polymerase (RdRp), and helicase. Both structural and functional proteins share essential roles in facilitating the entering of the virus to the host's target cells and then its intracellular propagation (Duan, Zhu, \& Zhou, 2020; Khozeimeh et al., 2021).

One of the most common manifestations of the COVID-19 disease is pneumonia. The patients present with complications such as cough, fever, and myalgia or fatigue. Laboratory analyses demonstrated high serum concertation of inflammatory cytokines (e.g., MCP-1, TNF- $\alpha$, IL-1 $\beta$, IL-10, IFN $\gamma$, and IL6), implying that the disease's severity is in part determined by the cytokine storm (Fig 1) (Huang et al., 2020).

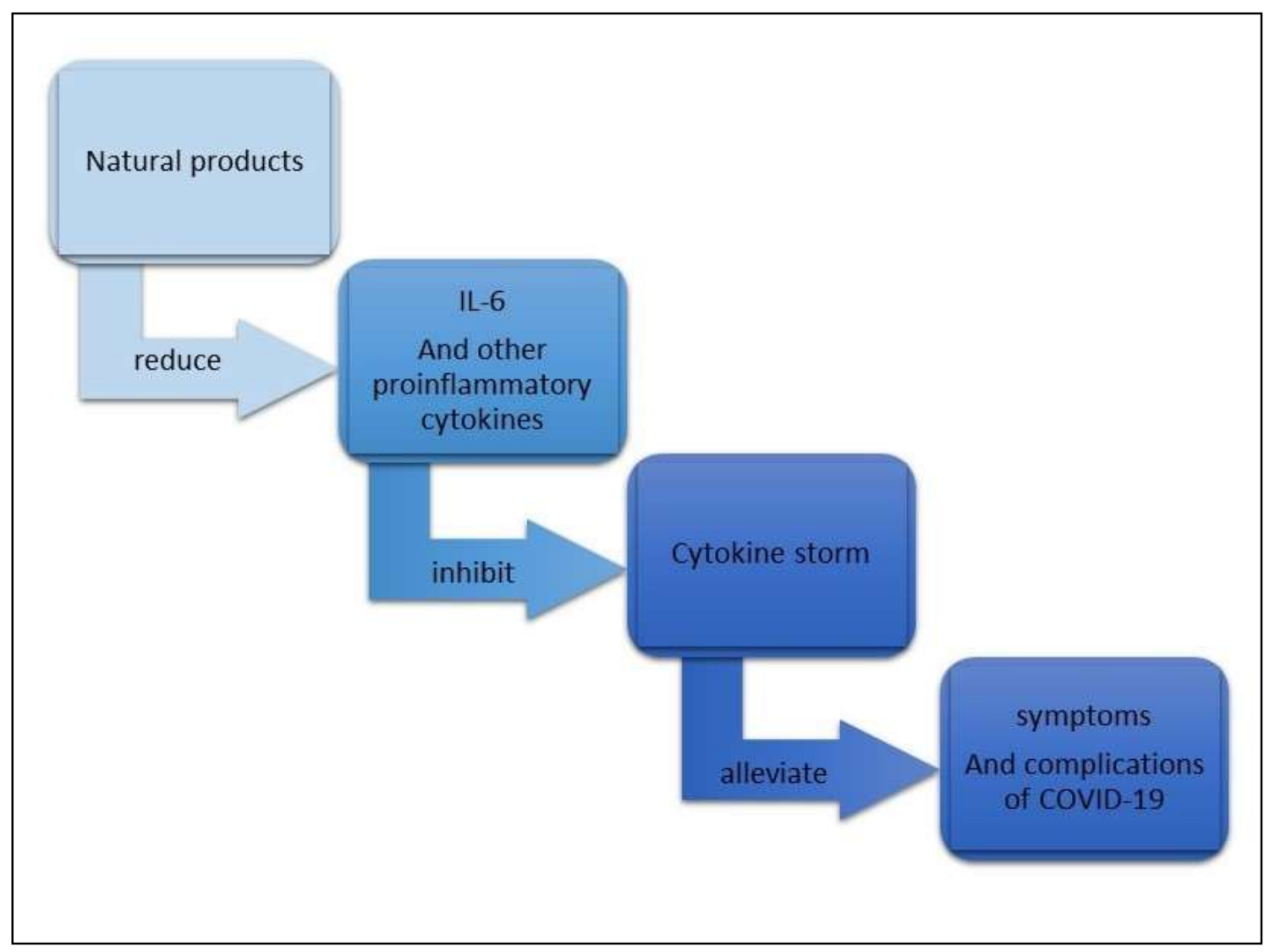

Figure 2. Graphical Abstract

\subsection{COVID-19 Pathogenesis and Immune response}

Regarding shape, COVID-19 resembles a spiky ball. To enter cells (i.e., the first step of pathogenesis), these spikes attach to ACE2, which is expressed on human cells. The interaction between ACE2 and these spikes enables the SARS-Cov2 to attach more strongly to the target cell. This phenomenon has been suggested to be a critical step in virus transmission between individuals 
(Kuster et al., 2020). Although the causative agent of COVID-19 seems to be primarily from an animal origin, it infects humans with high efficiency. Based on phylogenetic evidence, the SARS$\mathrm{CoV}-2$ is supposed to be a bat-derived virus, which somehow has managed, either directly or indirectly through another host, to infect human beings (C. Li, Yang, \& Ren, 2020).

The reaction of the immune system to the invading leads to fever and inflammation. However, the over-production of pro-inflammatory cytokines sometimes inflicts more detrimental than beneficial effects. In this regard, vasodilation facilitates the recruitment of leukocytes to the infection site. However, when vessels are exceedingly permeable, even fluids can enter and fill the lungs. Overall, these excessive immune reactions are known as the cytokine storm (Mehta et al., 2020; Yao et al., 2020).

During the cytokine storm due to the COVID-19 infection; however, not only the immune system is not overreacted, but it is also almost switched off, sparing actual pathogenic targets from being detected and eradicated. When this phenomenon occurs, patients become more susceptible to diseases causing by pathogenic or opportunistic bacteria. The cytokine storm and immune responses can influence the function of other body organs besides the respiratory system, particularly in the patients suffering from underlying chronic illnesses, explaining the incidence of some problems such as cardiac dysfunction and secondary microbial infections in a ratio of COVID-19 patients (Mehta et al., 2020).

Elderly individuals are at risk of more severe COVID-19, presumably because of their inability to muster an initial potent anti-viral response against the virus. On the other hand, the lower prevalence of COVID-19 in children has been attributed to the lack of the cytokine storm (Lloyd-Sherlock, Ebrahim, Geffen, \& McKee, 2020). Furthermore, other factors can influence the course of the disease, including the exposed viral load, genetic determinants, variations in immune responses, and other microorganisms in the body. The majority of COVID-19 related deaths occur in the elderly or those with underlying diseases such as pulmonary illnesses, cardiovascular problems, cancer, diabetes, etc. (Lai et al., 2020).

Researchers discovered that there was an increase in immunoglobulins rushing to fight the virus on days 7 to 9 following the disease's onset of symptoms. According to the present data, the elevated levels of antibodies are maintained over 20 days after symptoms' onset. During the days seventh to ninth after the emergence of symptoms, many specialized immune cells (i.e., B cells, killer $\mathrm{T}$ cells, and helper T cells) are detectable in patients' blood (Thevarajan et al., 2020). About $80 \%$ of COVID19 patients present with mild clinical symptoms or asymptomatic while the remainders progress to critical or severe acute conditions. The COVID-19 disease seems to have a milder clinical course in comparison with MERS or SARS; however, like the two recent diseases, COVID-19 also presents 
symptoms such as respiratory sequela (cough, dyspnea, sore throat), as well as systemic manifestations such as fatigue and fever (Guo et al., 2020). Also, most cases show pneumonia and lymphopenia, and on chest CT scan, specific pulmonary ground-glass opacity is detectable. Elevated levels of TNF $\alpha$, IL-10, IL-7, MCP-1, IL-2, IP-10, and G-CSF have been reported in patients with severe COVID-19 (Organization, 2020).

The cytokine storm and lymphopenia are assumed to be important determinants in COVID-19 progression. Inflammation-induced lung damage and viral sepsis can be followed by the cytokine storm, resulting in respiratory failure, acute respiratory distress syndrome, pneumonitis, organ dysfunction, shock, and finally, death. According to available data, the COVID-19 global mortality rate worldwide is nearly $2.4 \%$. Multi-organ dysfunction, especially in the elderly and patients with concurrent problems (e.g., diabetes, cardiovascular disease, hypertension, cancer) deems to be the main cause of death in COVID-19 patients (Prompetchara et al., 2020).

As it said before, cytokine storm has a significant impact on the mortality of persons with COVID-19. Proinflammatory cytokine has a crucial role in the process of the cytokine storm. Between these cytokines, IL-6 has a significant role in this process, and different investigations show the important effect of this cytokine on the cytokine storm. So, finding a new method that can inhibit this main interleukin can be a good idea for the suppression of cytokine storms and decrease the mortality of a person with COVID-19. Researches of investigators show that natural compounds are an excellent candidate for solving the story of interleukin-6 inhibition. Here are some of the natural compounds or herb that can be effective on inhibition of IL-6, and it shows the bold effect of natural Chinese herb as the pro-inflammatory agent (C. Chen, Zhang, Ju, \& He, 2020; Mehta et al., 2020; T. Zhang et al., 2020).

\subsection{Natural Products Inhibiting IL-6 During Cytokine Storm}

\subsubsection{Curcumin}

Curcumin is a natural yellow product isolated from the turmeric rhizome of the herb with the name Curcuma Longa. Many types of research showed an excellent efficiency of this product on different diseases such as diabetes, glioblastoma, Alzheimer's (Chainani-Wu, 2003; Chuengsamarn, Rattanamongkolgul, Luechapudiporn, Phisalaphong, \& Jirawatnotai, 2012; Dhandapani, Mahesh, \& Brann, 2007; Mishra \& Palanivelu, 2008). Anti-microbial, anti-viral, anti-fungal, anti-inflammatory, anti-carcinogenic, and antioxidant activity of curcumin (Menon \& Sudheer, 2007; Piper et al., 1998; Zorofchian Moghadamtousi et al., 2014). It also can be useful on different viruses such as HIV-1, $\mathrm{HCV}, \mathrm{EBV}, \mathrm{HCMV}, \mathrm{RSV}$, and influenza A. as it said before, curcumin has an excellent effect on inflammation (Mathew \& Hsu, 2018). a study by Y Xu et al. in vivo study showed that this product could be effective on influenza by promoting the expression of $\mathrm{IkB} \alpha$ and translocation of $\mathrm{p} 65$ to the 
nucleus and finally inhibition of NF-KB pathway(which is one of the pathways which can make different inflammatory cytokines) in a dose-dependent manner as a stock solution (Y. Xu \& Liu, 2017). Another study by Jainping et al. about the effect of curcumin on pneumonia, which is caused by influenza, shows that curcumin's ability in inhibition of oxidative stress, MPAK, and NF/KB, suppression of IFN- $\beta$, AKt, MMp-2 and9, IL-1 $\beta$, IL-6. This in vivo and in vitro study was done at the dosage of $25 \mu \mathrm{g}$ (J. Dai et al., 2018). Zhang et al. published a study on monocarbonyl analogs of curcumin (because of the low bioavailability and weak stability of curcumin, these analogs can make it more stable and the bioavailability of curcumin). This in vivo and in vitro study showed a positive effect of curcumin on inhibition of LPS-stimulated expression of some cytokines in macrophages, reducing TNF- $\alpha$ and IL-6 in a dose-dependent manner, and introduced curcumin as an excellent antiinflammatory agent (Y. Zhang et al., 2014). Another study by Peter p Sordillo said because of the effect of curcumin on blocking different cytokines such as IL-1, IL-10, IL-6, and TNF- $\alpha$, this compound is suggested as a very candidate for treatment Ebola and the severe viral infection by suppressing cytokine release and cytokine storm (figure 1) (Sordillo \& Helson, 2015).

\subsubsection{Andrographolide}

Andrographolide is one of the natural components with the name of Andrographis paniculate Nees. This product can be effective in the elimination of some toxic particles. It can cure the inflammation and oxidative stress level in different diseases like rheumatoid arthritis and hepatic fibrosis. This component can regulate the NF- $\mathrm{kB}$ and JAK-STAT pathways. In a dose-dependent manner, some derivation of this product like isoandrographolide,7-O-metylwogonin, and skullcapflavone-I can reduce the liberation of NO, interleukin- $1 \beta$, interleukin- 6 , prostaglandin $\mathrm{E} 2$ by in vitro and in vivo study. Using Andrographolide can effectively improve survival rate, reduce the accumulation of virus in cells, and diminish the expression of proinflammatory cytokines. This evidence shows that this product can be effective in injuring the lung (Yi Ding et al., 2017). Another study investigating the level of IL-6 in peripheral blood mononuclear cells of patients suffering from chronic rhinosinusitis with nasal polyps showed that Andrographolide diminished IL-6 expression (Kou et al., 2014). In a study by Nie et al., the effects of synthesized andrographolide derivatives on the production of proinflammatory cytokines were evaluated. The results revealed that compound $3 \mathrm{~b}$ was the most potent immune-suppressive derivative that inhibited the NF- $\mathrm{kB}$ pathway. Therefore it protects the lungs against acute infection(Nie et al., 2017). In conclusion, Andrographolide might be a promising therapeutic strategy for decreasing IL-6 expression and cytokine storm.

\subsubsection{Qiangzhi decoction (QZD)}

Qiangzhi decoction is a kind of compound that consisted of the four herbals with the name of Notopterygiuminicisum Ting Ex H. Chang, isatisindigotica Fort. (isatidis Folium), commelinacommunis L and Isatisindigotica Fort. This compound can be used against different 
viruses such as hepatitis B, herpetic, the corona. Recent studies showed that the significant effect of this compound on the reduction of pneumonia, which is caused by SARS. It is also used to treat xenograft fever (Matsukura et al., 1998; Pozzolini, Scarfì, Benatti, \& Giovine, 2003; Wang et al., 2008). In an in vivo and in vitro research by Zhu et al., the effect of this product is investigated on influenza pneumonia. Qianzhi decoction showed an excellent effect on survival rate; increasing titers of the virus, protection lung, and anti-viral activity of this virus were obviously clear. In a dosedependent manner, this compound can suppress some cytokine-like TNF- $\alpha$, IFN- $\alpha$, and IL- 6 and chemokines ICAM-1 and RANTED, especially at the dosage of $960 \mathrm{mg} /(\mathrm{kg}$. d) the best result is gained in the mice. This study also suggests this product as a good candidate for the treatment of influenza because of its ability to inhibit cytokine storms (Zhu et al., 2015).

\subsubsection{Alpha-mangostin}

Alpha-mangostin is a kind of bioactive compound that is isolated from the pericarp of mangosteen fruit. The different activity of this compound has been proved, such as anti-allergic, anti-parasitic, antioxidant, antiviral and antimicrobial, and antifungal (Ibrahim et al., 2016). moreover, the anticancer activity of this product is shown (P. Li, Tian, \& Ma, 2014). It uses as a traditional medicine in fever, diarrhea, and pain (Cui et al., 2010). Different studies show its efficiency on and HIV-1 and hepatitis C virus (S.-X. Chen, Wan, \& Loh, 1996; Choi, Kim, Lee, Chin, \& Lee, 2014). A study by Mayuri Tarasuk is done about the efficacy of this compound on dengue virus production and inhibition of cytokine storm. The result shows that it can reduce the rates of infection, make inhibition of virus and also be effective in the reduction of IL- 6 and TNF- $\alpha$ and on MIP-1 $\beta$, RANTES, and IP-10 chemokine at the dosage of $20 \mu \mathrm{g}$. This in vitro study was done, and the result shows that it can be more effective than ribavirin ( antiviral medicine ) and dexamethasone (an anti-inflammatory drug) (Tarasuk et al., 2017). ribavirin is introduced as one of the promising candidates for the treatment of the new coronavirus, and the effect of this antiviral agent in the coronavirus is shown (Elfiky, 2020). Alpha-mangostin showed its more potent activity than ribavirin in the study of Tarasurk and a good effect on the inhibition of cytokine storm. Thus hopefully, this compound may be a good agent for the treatment of people with coronavirus.

\subsubsection{Methyl 3-formyl-4-methyl pentanoate (SMFM)}

Allium savitum ( garlic) is used as a food, herbal medicine and has an excellent effect on different diseases such as cardiovascular diseases, cancer, some infection (Banerjee \& Maulik, 2002; Bolton, Null, \& Troetel, 1982; Fenwick, Hanley, \& Whitaker, 1985; Graham, Anderson, \& Lang, 1999; Milner, 2001). antibacterial and antiviral activity of this effective medicine also has been proved on influenza B and HSV (Yarnell, 2018). SMFM is a natural compound extracted from the herb with the name Allium sativum (garlic). 
In one study, Lee et al. showed that SMFM administration significantly reduced apoptosis in the lymphocytes derived from the spleen of cecal ligation and puncture (CLP), accompanied by a marked reduction in the number of bacterial colonies in the peritoneal fluid and a surge in the production of reactive oxygen species. SMFM also inhibited lung inflammation, raised the survival of mice, and reduced LPS-induced release of pro-inflammatory cytokines via blocking the NF-KB pathway. Furthermore, IL-6, IL-1 $\beta$, and TNF- $\alpha$ level significantly reduced at the doses of 15 and $10 \mathrm{mg} / \mathrm{kg}$ both in vivo and in vitro. This research suggested that SMFM could be an excellent agent for inhibiting the cytokine storm (Lee et al., 2015).

\subsubsection{Phillyrin}

Phillyrin, the dominant phytochemical of Oleaceae Fructus Forsythiae, possessing anti-inflammatory and anti-influenza A virus activity, might benefit from COVID-19 patients. At a dose of $20 \mathrm{mg} / \mathrm{kg} / \mathrm{day}$ for three days, administration of phillyrin considerably reduced the concentrations of IL-6 and attenuated lung tissue damage in mice during viral infection induced by influenza A virus. Taken together, phillyrin may have potent effects on protecting cells against viral infections through reducing inflammation (X.-y. Qu et al., 2016). Another study evaluated the modulatory effect of Phillyrin on pulmonary inflammation caused by LPS. Results indicated that Phillyrin attenuated the expression of inflammatory cytokines, including IL-6. Pretreatment with Phillyrin also decreased LPS-induced activation of the NF- $\mathrm{KB}$ pathway in lung tissues. The results showed the potential of Phillyrin as a protective agent against LPS-induced lung inflammation (Zhong et al., 2013).

\subsection{Ilex asprella}

The leaves and roots of a Chinese native herb (mainly found in Fujian, Guangxi, and Guangdong provinces), Ilex asprella (IA) (Hook. \& Arn.) Champ. ex Benth. (also known as "Gang-Mei") have been traditionally used to treat bacterial infections, pulmonary diseases such as influenza, and lung abscesses. The main constituents of this plant include alkaloid phenolic compounds, phenolic acid, and a triterpenoid called saponin (Qi \& Ren, 2009). The root extract of IA (500 mg/kg) was shown to reduce pulmonary inflammation and edema via suppressing the production of MCP-1, TNF- $\alpha$, and IL6 , accompanied by a rise in the serum levels of IFN- $\gamma$ and IL-10. In other words, IA effectively ameliorated the lung's viral load and improved pulmonary ventilation in the mice infected with the influenza virus (A/FM/1/47 H1N1). These results showed that IA extract was a potent herb to alleviate pulmonary inflammatory symptoms (W.-p. Dai et al., 2014).

\subsubsection{Theaflavins}

Theaflavins (TFs) are polyphenolic compounds existing in black tea. These compounds are produced by black tea dimerization and oxidation. Along with its three derivatives, TF has presented antiviral and anti-inflammatory effects against influenza (Henning et al., 2006; Robert, 1957). Zu M. et al. 
(2012) performed a study to investigate the anti-influenza effects and mechanisms of TFs, indicating that TFs, with a 50\% inhibitory concentration (IC50) ranging from 9.27 to $36.55 \mu \mathrm{g} / \mathrm{mL}$, inhibited the neuraminidase enzyme available in the H1N1 and H3N2 influenza virus strains. Furthermore, TFs were shown to inhibit hemagglutinin. So, TFs seem to promote their antiviral activities mainly via these mechanisms. In addition to suppressing virus-derived enzymes and other functional proteins, TF derivatives suppressed the release of IL-6, suggesting their anti-inflammatory and anti-influenza properties via blocking viral replication, as well as their potential to be used as a therapeutic agent (via blocking the cytokine storm) against the COVID-19 disease (Zu et al., 2012).

\subsubsection{Liu Shen Wan}

Liu Shen Wan (LSW) previously has been introduced as an anti-inflammatory antiviral compound. In vitro and in vivo studies showed that the NF- $\mathrm{kB}$ pathway and the expression of inflammatory cytokines, including IL-6, are limited by LSW. Moreover, LSW can effectively inhibit influenza virus replication in mice and virus-infected cells and improve survival time. LSW diminishes a load of virus and pathological changes in the lungs. The mechanism of LSW is on down regulatory effect on inflammatory cytokines expression; thus, it can be a useful novel choice to hinder the cytokine storm in the (Ma, Huang, Zhao, \& Yang, 2020).

\subsubsection{Naringin}

Wild citrus (Citrus fruit peel) contains abundant amounts of flavonoids. It has been shown to alleviate cough, promote digestive function, and augment the immune system's response against pathogens, including viruses (Lin et al., 2005). Recently, Cheng et al. (2020) assessed the efficacy of six flavonoids derived from three citrus species and showed that naringin $(4 \mathrm{mg} / \mathrm{kg}$ per rat) suppressed the LPS-induced production of proinflammatory cytokines (IL-6, IL-1 $\beta$, iNOs, and COX-2) in the Raw macrophage cell line, in vivo, and in vitro. This inhibiting effect was suggested to be related to the suppression of HMGB1 expression, based on an experiment in mice. So, flavonoids can project antiinflammatory and anti-coronavirus effects, implying that citrus fruit and its derived phytochemicals can effectively treat the 2019-nCoV infection (Cheng et al., 2020).

\subsubsection{Shen-Fu}

As a traditional Chinese herb, Shen-Fu (SF) comprises Fuzi (Radix Aconitum Carmichaeli, AC) and Ginseng (Radix Ginseng, RG). Chinese have traditionally utilized this plant to manage and treat endstage diseases, MODS, shock, and China (Wu et al., 2016). Quian Y et al. (2006) assessed the impacts of Shen-Fu (at the doses of 10 and $100 \mathrm{mg} / \mathrm{kg}$ ) on acute pulmonary injury following endotoxin administration in adult male Wistar rats. They observed that the plant suppressed the induction of NFkappa B by the endotoxin and subsequently reduced the production of IL- 6 and TNF- $\alpha$ and activation of myeloperoxidase (MPO). Furthermore, at a dose of $>10 \mathrm{mg} / \mathrm{kg}$, Shen-Fu alleviated lung 
inflammation in the animals exposed to the endotoxin. Considering the effects mentioned above of $\mathrm{Shen}-\mathrm{Fu}$ on the function of the immune system and its role in modulating inflammatory pathways, this herb can be used to curb the spread of COVID-19 and treat its complications (Qian, Sun, Wang, \& Yang, 2006).

\subsubsection{Xuebijing}

Xuebijing is a kind of Chinese medicine that is a combination of 5 natural herbs: Dangguie ( Radix angelica Sinensis), Chishao (Radix angelica rubera ), Chuanxiong (Rhizoma chuanxiong), Danshen (Radix salvia Miltiorrhizae) and Honghua (Flos carthami). It uses for the treatment of sepsis and septic shock, and early injection of this natural product can be useful in people with severe trauma (He, Tan, Zhang, \& Guo, 2015; Jiang et al., 2013; LU, GU, \& Huang, 2010; Shi, Hong, Qian, Cai, \& Chen, 2017). This compound can make the activation of blood circulation, removing blood stasis, and cooling the blood. One study on 80 patients with pneumonia showed that the combination of antibiotics and this compound could reduce the LDH serum level, daily peak body temperature, CRP, and suppress TNF- $\alpha$, IL-6, and IL- 8 at the dosage of $50 \mathrm{ml}$ of this product on $100 \mathrm{ml}$ normal saline (Fei, LIANG, SHE, Guang-Tao, \& CHEN, 2011). Another study by Xi chen et al. about the proinflammatory and anti-inflammatory Th17 and T regulatory effect of Xuebijing on the group of sepsis mice shows that this compound can improve the survival by induction of FoxP3 and IL-10 expression on CD4 T cell, regulation of Treg (an anti-inflammatory agent) and TH17 (pro-inflammatory agent), prevention of neutrophil infiltration into lung and kidney at the dosage of $18 \mathrm{ml} / \mathrm{kg}$. This vitro study also shows a significant reduction of some cytokines like TNF- $\alpha$ and IL-6, reduction of this cytokine can regulate the Treg by releasing the repression of FoxP3, which IL-6 inhibits. With these features of Xuebijing in this study, it introduces another agent to prevent the cytokine storm (X. Chen et al., 2018).

\subsubsection{Chai-hu-gui-zi-gan-jiang-tang}

This compound is prepared by (saiko-keishi-kankyo-to) combining parts of seven herbal medicines (i.e., bupleurum root (6 g) along with $3 \mathrm{~g}$ of each oyster shell, cinnamon bark, sctellaria, and trichosanthe root and; and $2 \mathrm{~g}$ of dried ginger rhizome and glycyrrhiza root). Although this compound usually has no effects on the diseases caused by climate changes or mood fluctuations, it can treat neurological disorders, insomnia, depression, fatigue, and some psychiatric problems (Aizawa et al., 2002; lizuka et al., 1998).

In a study by Ushiroyama T. et al. (2005), 90 women with menopausal problems such as insomnia diagnosed the mood disorder were assigned to two experimental groups to receive either $7.5 \mathrm{~g}$ of a commercial drug (an anti-depressant agent) or Chai-hu-gui-zhi-gan-jiang-tang. Compared with the women treated with the anti-depressant, serum sIL-6 was significantly lower in the women treated 
with the recent compound, suggesting the beneficial effects of Chai-hu-gui-zhi-gan-jiang-tang in the attenuation of peri- and post-menopausal women's morbidities and reducing their stress reactions, as well as diminishing soluble interleukin-6 receptor, IL-6, and TNF- $\alpha$ (Ushiroyama, Ikeda, Sakuma, \& Ueki, 2005).

\subsubsection{Lidanpaidu prescription (LDP)}

Lidanpaidu prescription (LDP), is a composition of classical Chinese herbs, including salvia, gardenia, capillary artemisia, and six other Chinese traditional herbs. The anticoagulant, antiendotoxin, and various other biological functions have been attributed to this compound, suggesting it as a beneficial agent against trauma and urinary tract infections (W.-j. Li, Wang, \& Wang, 2013). Zhang F. et al. (2017) used different concentrations of LPD (37.5, 75, and $150 \mathrm{~g} / \mathrm{kg}$ ) to assess its preventive effects and potential mechanisms in the mice models of acute kidney injury (AKI) induced by LPS. This study showed a significant improvement in the survival (66.7\%) of the mice pre-treated $(48 \mathrm{~h})$ with LDP respective to the mice only challenged with LPS $(26.7 \%)$. In addition, LPS-induced renal histopathological changes improved, and inflammatory cytokines decreased in the kidney and serum samples of LDP-treated mice, suggesting a protective role for LDP against LPS-induced AKI, probably mediated by the suppression of the NF- $\kappa$ B pathway (i.e., an antiinflammatory activity). This effect can also be extrapolated to pulmonary infection and injury. So, some of the anti-inflammatory effects of this compound may attenuate the cytokine storm (F. Zhang et al., 2018).

\subsubsection{Chlorogenic acid}

Chlorogenic acid (CHA), which is rich in a Chinese herbal plant like Lonicera japonica Thunb, Crataegus monogyna, and Vaccinium Angustifolia, can be a good component in the treatment of different virus such as HIV, adenovirus, HSV, hepatitis B. also, it can be good in inhibition of viral infection. It can also be effective on infections related to upper respiratory tracts such as influenza and parainfluenza. In Vivo and in vitro study showed the efficacy of CHA in combatting influenza A (H1N1/H3N2) and strains resistant to oseltamivir. CHA hinders releasing particles of the newly formed virus from cells that are infected through inhibition of neuraminidase. Injection at the dosage of $100 \mathrm{mg} / \mathrm{kg} / \mathrm{d}$ shows that this product can reduce TNF- $\alpha$ and interleukin- 6 in cellular and animal models. Due to the significant reduction of inflammation in the lungs, improving the survival of cells, and decreasing the concentration of virus titers, CHA was introduced as a good candidate for reducing inflammation (Yue Ding et al., 2017).

\subsubsection{4-Deoxy-11,12-didehydroandrographolide(DAP)}

14-Deoxy-11,12-didehydroandrographolide (DAP) is a component of Andragraphis paniculate. This herb exhibits multiple biological features (e.g., immunomodulatory function, antibacterial, antiviral, 
anti-inflammatory, antipyretic, analgesic, etc.) (Ge et al., 2010; Guan, Kong, Cheng, Lim, \& Wong, 2011). In a study by Cai W. et al. on mice, it was shown that DAP treatment ( $4 \mathrm{~h}$ before the infection) significantly reduced weight loss and mortality $(1000 \mathrm{mg} / \mathrm{kg} /$ day) and lung virus load (1000 or 500 $\mathrm{mg} / \mathrm{kg} /$ day) in the mice exposed to H1N1 or H5N1 influenza A viruses, accompanied with reduced oxidative stress and the mRNA levels of MIP-1 $\beta$, MIP- $1 \alpha$, IFN- $\beta$, IFN- $\alpha$, IL- 6 , TNF- $\alpha$, and IL- 1 . So, regarding the effects of DAP against IAVs and its anti-inflammatory properties, this agent, a derivative of A. paniculata, can be a viable therapeutic option for patients with COVID19 (Cai et al., 2016).

\subsubsection{Forsythia Chinese Medicine}

Forsythia suspensa is an herbal medicine traditionally used by Asians to alleviate inflammation, flu symptoms, and fever. In recent times, this plant has been under attention for its beneficial effects against a variety of inflammatory diseases such as pharyngitis, tonsillitis, pyrexia, erysipelas, as well as ulcers and several other conditions (H.-B. Li \& Chen, 2005; H. Qu, Zhang, Wang, Li, \& Sun, 2008). Moreover, it has been shown that the flavonols and lignans (i.e., phenolic compounds) available in the crude extract of this plant have antipyretic, choleretic, as well as antibacterial and antiviral properties (Piao, Jang, Cui, \& Piao, 2008). A study by Coon TA et al. (2014) developed murine models of bacterial and viral pneumonia to investigate the effects of several derivatives of Forsythin as novel selective inhibitors of PDE in vivo and in vitro. These compounds seemed to be highly effective at the dose of $<1 \mathrm{mg} / \mathrm{kg}$ to alleviate the symptoms of LPS-induced pneumonia and sepsis in animal models by decreasing inflammatory cells, protein concentrations, and TNF- $\alpha$ and IL6 levels in lavage, correlated with a reduction in serum cytokines levels, in the mice exposed to H1N1-induced systematic inflammation (figure 2). According to the mentioned findings, selective PDE4 inhibitors could maintain pulmonary homeostasis via modulating lung inflammation following infection with the H1N1 influenza virus (Coon et al., 2014). 


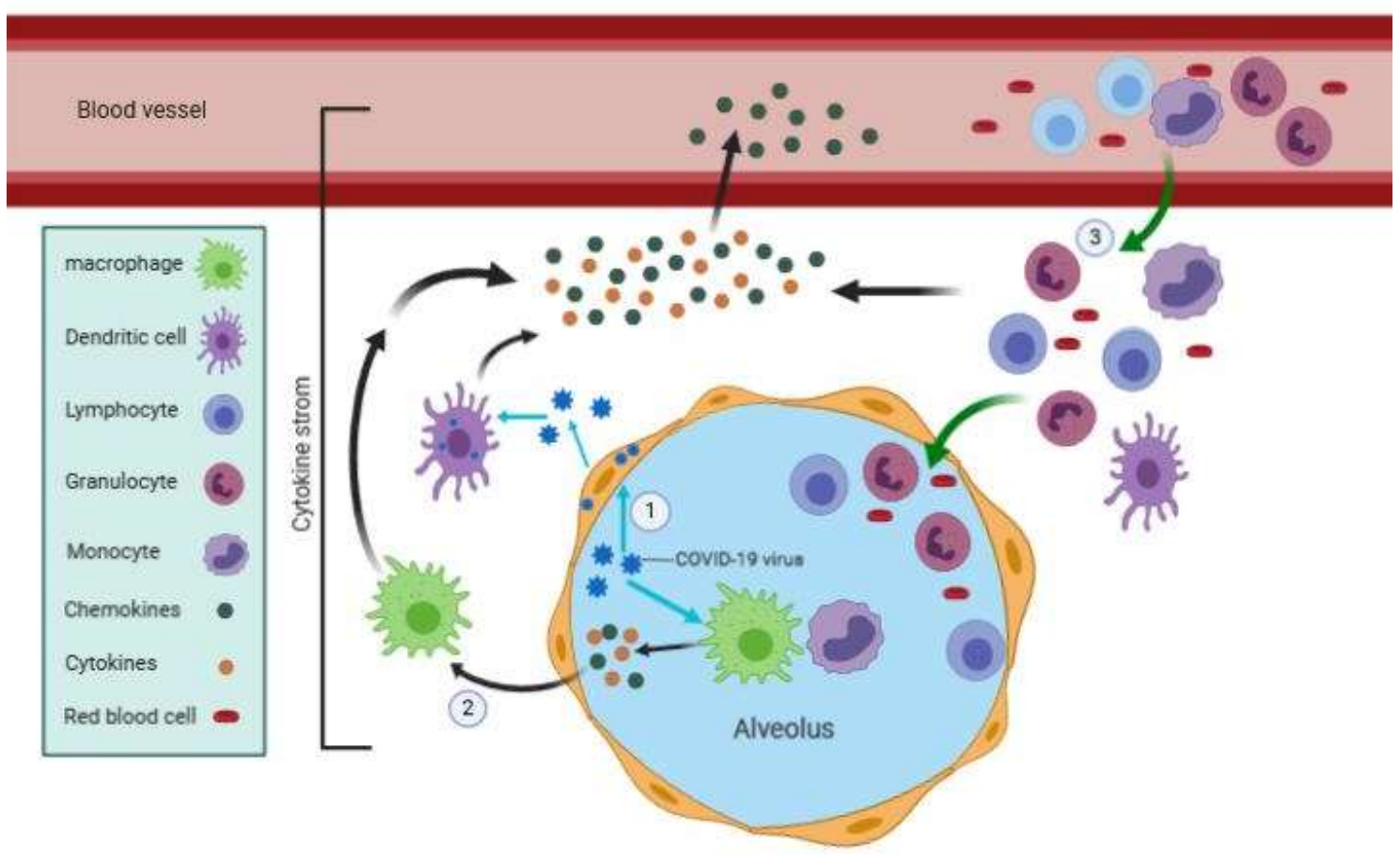

Figure 2. Cytokine storm in the lung following COVID-19 infection.

\section{Conclusion}

COVID-19 is a newly emerged disease caused by a new member of the coronavirus family with SARS-COV-2. It has been postulated that cytokine storm is a primary reason for morbidity and mortality due to this disease. Tocilizumab is one the best blocker of the IL-6 signal transduction pathway, and recent investigations introduced that as a good candidate for reduction of cytokine storm and improve the patients with COVID-19 (X. Xu et al., 2020; C. Zhang, Wu, Li, Zhao, \& Wang, 2020). Interleukin-6 has been suggested as a critical mediator during cytokine storms and thus represents an important therapeutic target for developing drugs against COVID-19. Plant-derived natural products have emerged as promising candidates for the inhibition of IL-6. In this review, we elaborated the findings of cellular and experimental studies delineating the role of IL- 6 as a target of therapy in COVID-19. Overall, 17 natural products and medicinal plants were found as potentially helpful in the treatment of COVID-19. It is believed all of these natural products and medicinal plants have a good effect on IL-6 expression during viral infections, Phillyrin and SMFM and Qiangzhi decoction and curcumin and Shen-fu and Forsythia and Alpha-mangostin have reductive efficiency on the production of IL-6, Andrographolide, and Liu Shen Wan have an inhibitory effect on releasing this agent, Ilex asprella and Deoxy-11,12-didehydroandrographolide and Naringin reduce the expression of IL-6. Theaflavin and Cholorogenic acid inhibit the secretion of IL-6, Xuebijing, and Chai-hu-gui-zi-gan-jiang-tang and Lipanpaidu prescription can reduce the serum level of IL-6. Notably, Andrographolide and curcumin are two candidates potential to inhibit the IL-6 expression. 
Because of the gnificant role of curcumin on suppression of IL- 6 and other agents and impressive effect of this agent in the improvement of lungs in different infections of lung especially on the family of coronavirus and salient reductive potency of Andrographolide on releasing of IL-6 and crucial impact of that on viral infections of lung in particular CORONAVIRUS family members, we especially nominate these two agents as a good factors to inhibit IL-6 and cytokines storm in patients with COVID-19. We firmly suggest that the natural products reviewed here are possible agents for reducing cytokine storm, thus providing a suitable way to prevent and treat COVID-19 in combination with other drugs and agents or alone. However, we recommend that more clinical trials about the

Table 1. Effects of reviewed natural compounds on cytokine storm in infectious diseases

\begin{tabular}{|c|c|c|c|c|c|}
\hline Natural product & $\begin{array}{c}\text { Pathogen }(\mathbf{s}) / \\
\text { inflammation } \\
\text { inducer }\end{array}$ & Dose (s) & $\begin{array}{c}\text { In-vivo/ In- } \\
\text { vitro }\end{array}$ & Effect (s) & Ref \\
\hline \multirow{3}{*}{ Curcumin } & LPS & $\begin{array}{c}\text { Dose } \\
\text { dependent } \\
\text { manner }\end{array}$ & $\begin{array}{l}\text { Both in vivo } \\
\text { and in vitro }\end{array}$ & $\begin{array}{l}\text { Reduction of TNF-alpha and IL- } 6 \text { in } \\
\text { Septic mouse model }\end{array}$ & $\begin{array}{l}\text { (Y. Zhang et } \\
\text { al., 2014) }\end{array}$ \\
\hline & $\begin{array}{l}\text { Influenza A } \\
\text { virus }\end{array}$ & $25 \mu \mathrm{g}$ & $\begin{array}{l}\text { Both in vivo } \\
\text { and in vitro }\end{array}$ & $\begin{array}{l}\text { Inhibition of Nf-kB, MPAK, oxidative } \\
\text { stress, suppression of IFN-beta, AKT, } \\
\text { MMP-2, MMP-9, IL-6 }\end{array}$ & $\begin{array}{l}\text { (J. Dai et } \\
\text { al., 2018) }\end{array}$ \\
\hline & $\begin{array}{l}\text { Influenza A } \\
\text { virus }\end{array}$ & $\begin{array}{c}\text { Dose } \\
\text { dependent } \\
\text { manner }\end{array}$ & In vivo & $\begin{array}{l}\text { Inhibition of Nf-kB and translocation } \\
\text { of } p 65 \text { to nucleus }\end{array}$ & $\begin{array}{l}\text { (Y. Xu \& } \\
\text { Liu, 2017) }\end{array}$ \\
\hline \multirow{3}{*}{ Andrographolide } & $\begin{array}{l}\text { Influenza A } \\
\text { (H1N1) }\end{array}$ & $\begin{array}{l}\text { Dose- } \\
\text { dependent } \\
\text { manner }\end{array}$ & $\begin{array}{l}\text { Both in vivo } \\
\text { and in vitro }\end{array}$ & $\begin{array}{l}\text { Reduce NO, IL-1 } \beta \text {, IL-6, } \\
\text { prostaglandin E2 via down regulating } \\
\text { the NF-אB and JAK-STAT pathways }\end{array}$ & $\begin{array}{l}\text { (Yi Ding et } \\
\text { al., 2017) }\end{array}$ \\
\hline & Not applicable & $8 \mu \mathrm{g} / \mathrm{mL})$ & In vitro & Inhibiting IL-6 & $\begin{array}{l}\text { (Kou et al., } \\
\text { 2014) }\end{array}$ \\
\hline & & $\begin{array}{c}\text { Dose } \\
\text { dependent } \\
\text { manner }\end{array}$ & In vivo & Inhibiting NF- $\kappa B$ pathway & $\begin{array}{l}\text { (Nie et al., } \\
\text { 2017) }\end{array}$ \\
\hline
\end{tabular}

efficiency of these agents is totally necessary. 


\begin{tabular}{|c|c|c|c|c|c|}
\hline $\begin{array}{l}\text { Qiangzhi } \\
\text { decoction (QZD) }\end{array}$ & Influenza A & $\begin{array}{l}\text { Dose } \\
\text { dependent } \\
\text { manner } \\
\text { (especially in } \\
960 \mathrm{mg} / \mathrm{kg} . \mathrm{d} \text { ) }\end{array}$ & $\begin{array}{l}\text { Both in Vivo } \\
\text { and in vitro }\end{array}$ & $\begin{array}{l}\text { Suppress of TNF- } \alpha \text {, IFN- } \alpha \text {, IL- } 6 \text {, } \\
\text { chemokine ICAM- } 1 \text { and chemokine } \\
\text { RANTED, inhibition of cytokine } \\
\text { storm. }\end{array}$ & $\begin{array}{l}\text { (Zhu et al., } \\
\text { 2015) }\end{array}$ \\
\hline Alpha-mangostin & Dengue virus & $20 \mu \mathrm{g}$ & In vitro & $\begin{array}{l}20 \text { microgeram } \\
\text { Reduction of IL- } 6 \text {, TNF- } \alpha \text {, and IP-10 } \\
\text { (CXCL10) chemokine, MIP-1beta } \\
\text { And RANTED }\end{array}$ & $\begin{array}{l}\text { (Tarasuk et } \\
\text { al., 2017) }\end{array}$ \\
\hline$S M F M$ & LPS & $\begin{array}{l}15 \text { and } 10 \\
\mathrm{mg} / \mathrm{kg}\end{array}$ & $\begin{array}{l}\text { Both in vivo } \\
\text { and in vitro }\end{array}$ & $\begin{array}{l}\text { Inhibition of NF-kB, reduction of } \\
\text { TNF- } \alpha, \text { IL-1 } \beta, \text { IL-6 }\end{array}$ & $\begin{array}{l}\text { (Lee et al., } \\
\text { 2015) }\end{array}$ \\
\hline \multirow{2}{*}{ Phillyrin } & $\begin{array}{l}\text { Influenza A } \\
\text { virus }\end{array}$ & $20 \mathrm{mg} / \mathrm{kg} /$ day & In vivo & Inhibiting IL-6 & $\begin{array}{l}\text { (X.-y. Qu et } \\
\text { al., 2016) }\end{array}$ \\
\hline & LPS & $5 \mathrm{mg} / \mathrm{kg}$ & In vivo & Inhibiting IL-6 and NF- $\kappa$ B pathway & $\begin{array}{l}\text { (Zhong et } \\
\text { al., 2013) }\end{array}$ \\
\hline Ilex asprella & $\begin{array}{l}\text { the influenza } \\
\text { H1N1 virus }\end{array}$ & $500 \mathrm{mg} / \mathrm{kg}$ & In vivo & $\begin{array}{l}\text { Depressed the expression of IL- } 6 \text {, } \\
\text { TNF- } \alpha \text { and MCP-1, and increased the } \\
\text { expression of IL-10 and IFN- } \gamma \text { in } \\
\text { serum }\end{array}$ & $\begin{array}{l}\text { (W.-p. Dai } \\
\text { et al., 2014) }\end{array}$ \\
\hline Theaflavins & $\begin{array}{l}\text { H5N1 or H1N1 } \\
\text { influenza A } \\
\text { viruses }\end{array}$ & $\begin{array}{l}1,5 \text { or } 25 \\
\mu \mathrm{g} / \mathrm{mL}\end{array}$ & in vitro & $\begin{array}{l}\text { Decreased the expression level of the } \\
\text { inflammatory cytokine IL-6 }\end{array}$ & $\begin{array}{l}\text { (Zu et al., } \\
\text { 2012) }\end{array}$ \\
\hline Liu Shen Wan & $\begin{array}{c}\text { Influenza A } \\
\text { virus }\end{array}$ & $\begin{array}{c}100 \mathrm{mg} / \mathrm{kg} \text { and } \\
50 \mathrm{mg} / \mathrm{kg}\end{array}$ & $\begin{array}{l}\text { Both in Vivo } \\
\text { and in vitro }\end{array}$ & Inhibiting NF- $\kappa \mathrm{B}$ pathway & $\begin{array}{l}\text { (Ma et al., } \\
\text { 2020) }\end{array}$ \\
\hline Naringin & $\begin{array}{l}\text { LPS (Raw } \\
\text { macrophage cell } \\
\text { line) }\end{array}$ & $4 \mathrm{mg} / \mathrm{kg}$ & $\begin{array}{l}\text { Both in Vivo } \\
\text { and in vitro }\end{array}$ & $\begin{array}{l}\text { Inhibit the expression of the pro- } \\
\text { inflammatory cytokines (COX-2, } \\
\text { iNOS, IL-1 } \beta \text { and IL-6) } \\
\text { restrain cytokine through inhibiting } \\
\text { HMGB1 expression }\end{array}$ & $\begin{array}{l}\text { (Cheng et } \\
\text { al., 2020) }\end{array}$ \\
\hline Shen-Fu & LPS (endotoxin & $10,100 \mathrm{mg} / \mathrm{kg}$ & in vivo & Decreased MPO (Myeloperoxidase) & (Qian et al., \\
\hline
\end{tabular}




\begin{tabular}{|c|c|c|c|c|c|}
\hline & $\begin{array}{l}\text { induced acute } \\
\text { lung injury on } \\
\text { adult male } \\
\text { Wistar) }\end{array}$ & & & $\begin{array}{l}\text { activity and inhibited TNF- } \alpha \text { and IL- } 6 \\
\text { production, endotoxin-induced NF- } \kappa \text { B } \\
\text { activation }\end{array}$ & 2006) \\
\hline \multirow[t]{2}{*}{ Xuebijing } & $\begin{array}{l}\text { Cecal ligation } \\
\text { and puncture } \\
\text { (CLP) model } \\
\text { Mice (fecal } \\
\text { pathogens) }\end{array}$ & $18 \mathrm{mg} / \mathrm{kg}$ & In vitro & $\begin{array}{l}\text { Induction of FoxP3 and IL-10, } \\
\text { regulation of Treg and Th17, reduce } \\
\text { TNF- } \alpha \text { and IL- } 6\end{array}$ & $\begin{array}{l}\text { (X. Chen et } \\
\text { al., 2018) }\end{array}$ \\
\hline & $\begin{array}{l}\text { Severe } \\
\text { pneumonia } \\
\text { pathogen }\end{array}$ & $\begin{array}{l}50 \mathrm{ml} \\
\text { xuebijing in } \\
100 \mathrm{ml} \text { normal } \\
\text { saline }\end{array}$ & In vivo & $\begin{array}{l}\text { Reduction LDH serum level, daily } \\
\text { temperature, CRP, suppression TNF- } \\
\alpha, \text { IL-6, IL-8 }\end{array}$ & $\begin{array}{l}\text { (Fei et al., } \\
\text { 2011) }\end{array}$ \\
\hline $\begin{array}{l}\text { Chai-hu-gui-zi- } \\
\text { gan-jiang-tang }\end{array}$ & $\mathrm{N} / \mathrm{A}$ & $\begin{array}{l}7.5 \mathrm{~g} \text { per each } \\
\text { women }\end{array}$ & In vivo & $\begin{array}{l}\text { Plasma IL-6 and sIL-6R } \\
\text { concentrations significantly decrease }\end{array}$ & $\begin{array}{l}\text { (Ushiroyam } \\
\text { a et al., } \\
\text { 2005) }\end{array}$ \\
\hline $\begin{array}{l}\text { Lipanpaidu } \\
\text { prescription } \\
\text { (LDP) }\end{array}$ & LPS & $\begin{array}{l}37.5,75 \text { and } \\
150 \mathrm{~g} / \mathrm{kg}\end{array}$ & $\begin{array}{l}\text { Both in vivo } \\
\text { and in vitro }\end{array}$ & $\begin{array}{l}\text { Suppression of the NF- } \mathrm{KB} \text { signaling } \\
\text { pathway and significant reduction in } \\
\text { TNF- } \alpha \text { and IL-6 }\end{array}$ & $\begin{array}{l}\text { (F. Zhang et } \\
\text { al., 2018) }\end{array}$ \\
\hline $\begin{array}{l}\text { Chlorogenic } \\
\text { Acid }\end{array}$ & $\begin{array}{l}\text { Influenza A } \\
\text { (H1N1/ } \\
\text { H3N2) }\end{array}$ & $100 \mathrm{mg} / \mathrm{kg} / \mathrm{d}$ & $\begin{array}{l}\text { Both in vivo } \\
\text { and in vitro }\end{array}$ & Reduce the level of TNF- $\alpha$ and IL- 6 & $\begin{array}{l}\text { (Yue Ding } \\
\text { et al., 2017) }\end{array}$ \\
\hline $\begin{array}{l}\text { 14-Deoxy-11, 12- } \\
\text { didehydroandrogr } \\
\text { apholide (DAP) }\end{array}$ & $\begin{array}{l}\text { H5N1 or H1N1 } \\
\text { influenza A } \\
\text { viruses }\end{array}$ & $\begin{array}{l}1000 \text { or } 500 \\
\mathrm{mg} / \mathrm{kg} / \text { day }\end{array}$ & In vivo & $\begin{array}{l}\text { Reduction in the mRNA levels of } \\
\text { TNF- } \alpha \text {, IL-1, IL- } 6 \text {, IFN- } \alpha \text {, IFN- } \beta \text {, } \\
\text { MIP-1 } \alpha \text {, MIP-1 } \beta\end{array}$ & $\begin{array}{l}\text { (Cai et al., } \\
\text { 2016) }\end{array}$ \\
\hline $\begin{array}{l}\text { Forsythia Chinese } \\
\text { Medicine }\end{array}$ & $\begin{array}{l}\text { LPS } \\
\text { influenza A } \\
\text { H1N1 }\end{array}$ & $\begin{array}{l}0.01,0.1,1 \text { and } \\
10 \mathrm{mg} / \mathrm{kg}\end{array}$ & $\begin{array}{l}\text { Both in vivo } \\
\text { and in vitro }\end{array}$ & $\begin{array}{l}\text { Decreased lavage cell counts, protein } \\
\text { concentrations, and lavage cytokine } \\
\text { IL-6 and TNF and also reduced serum } \\
\text { cytokines }\end{array}$ & $\begin{array}{l}\text { (Coon et al., } \\
\text { 2014) }\end{array}$ \\
\hline
\end{tabular}




\section{References}

Aizawa, R., Kanbayashi, T., Saito, Y., Ogawa, Y., Sugiyama, T., Kitajima, T., . . Shimizu, T. (2002). Effects of Yoku-kan-san-ka-chimpi-hange on the sleep of normal healthy adult subjects. Psychiatry and Clinical Neurosciences, 56(3), 303-304.

Alizadehsani, R., Alizadeh Sani, Z., Behjati, M., Roshanzamir, Z., Hussain, S., Abedini, N., . . Islam, S. M. S. (2021). Risk factors prediction, clinical outcomes, and mortality in COVID-19 patients. Journal of Medical Virology, 93(4), 2307-2320. doi:https://doi.org/10.1002/jmv.26699

Alizadehsani, R., Sharifrazi, D., Izadi, N. H., Joloudari, J. H., Shoeibi, A., Gorriz, J. M., . . . Khozeimeh, F. (2021). Uncertainty-Aware Semi-supervised Method using Large Unlabelled and Limited Labeled COVID-19 Data. arXiv preprint arXiv:2102.06388.

Ayoobi, N., Sharifrazi, D., Alizadehsani, R., Shoeibi, A., Gorriz, J. M., Moosaei, H., . . Goni, F. A. (2021). Time Series Forecasting of New Cases and New Deaths Rate for COVID-19 using Deep Learning Methods. arXiv preprint arXiv:2104.15007.

Banerjee, S. K., \& Maulik, S. K. (2002). Effect of garlic on cardiovascular disorders: a review. Nutrition journal, 1(1), 4.

Bolton, S., Null, G., \& Troetel, W. M. (1982). The medical uses of garlic fact and fiction. American pharmacy, 22(8), 40-43.

Cai, W., Chen, S., Li, Y., Zhang, A., Zhou, H., Chen, H., \& Jin, M. (2016). 14-Deoxy-11, 12didehydroandrographolide attenuates excessive inflammatory responses and protects mice lethally challenged with highly pathogenic A (H5N1) influenza viruses. Antiviral research, 133, 95-105.

Chainani-Wu, N. (2003). Safety and anti-inflammatory activity of curcumin: a component of tumeric (Curcuma longa). The Journal of Alternative \& Complementary Medicine, 9(1), 161-168.

Chen, C., Zhang, X., Ju, Z., \& He, W. (2020). Advances in the research of cytokine storm mechanism induced by Corona Virus Disease 2019 and the corresponding immunotherapies. Zhonghua shao shang za zhi= Zhonghua shaoshang zazhi= Chinese journal of burns, 36, E005.

Chen, S.-X., Wan, M., \& Loh, B.-N. (1996). Active constituents against HIV-1 protease from Garcinia mangostana. Planta medica, 62(04), 381-382.

Chen, X., Feng, Y., Shen, X., Pan, G., Fan, G., Gao, X., . . Zhu, Y. (2018). Anti-sepsis protection of Xuebijing injection is mediated by differential regulation of pro-and anti-inflammatory Th17 and $\mathrm{T}$ regulatory cells in a murine model of polymicrobial sepsis. Journal of ethnopharmacology, 211, 358-365.

Cheng, L., Zheng, W., Li, M., Huang, J., Bao, S., Xu, Q., \& Ma, Z. (2020). Citrus Fruits Are Rich in Flavonoids for Immunoregulation and Potential Targeting ACE2.

Choi, M., Kim, Y.-M., Lee, S., Chin, Y.-W., \& Lee, C. (2014). Mangosteen xanthones suppress hepatitis C virus genome replication. Virus genes, 49(2), 208-222.

Chuengsamarn, S., Rattanamongkolgul, S., Luechapudiporn, R., Phisalaphong, C., \& Jirawatnotai, S. (2012). Curcumin extract for prevention of type 2 diabetes. Diabetes care, 35(11), 2121-2127.

Coon, T. A., McKelvey, A. C., Weathington, N. M., Birru, R. L., Lear, T., Leikauf, G. D., \& Chen, B. B. (2014). Novel PDE4 inhibitors derived from Chinese medicine forsythia. PloS one, 9(12).

Cui, J., Hu, W., Cai, Z., Liu, Y., Li, S., Tao, W., \& Xiang, H. (2010). New medicinal properties of mangostins: Analgesic activity and pharmacological characterization of active ingredients from the fruit hull of Garcinia mangostana L. Pharmacology Biochemistry and Behavior, 95(2), 166-172.

Dai, J., Gu, L., Su, Y., Wang, Q., Zhao, Y., Chen, X., . . . Li, K. (2018). Inhibition of curcumin on influenza A virus infection and influenzal pneumonia via oxidative stress, TLR2/4, p38/JNK MAPK and NF- $\mathrm{KB}$ pathways. International immunopharmacology, 54, 177-187.

Dai, W.-p., Li, G., Li, X., Hu, Q.-p., Liu, J.-x., Zhang, F.-x., . . . Lai, X.-p. (2014). The roots of Ilex asprella extract lessens acute respiratory distress syndrome in mice induced by influenza virus. Journal of ethnopharmacology, 155(3), 1575-1582. 
Dhandapani, K. M., Mahesh, V. B., \& Brann, D. W. (2007). Curcumin suppresses growth and chemoresistance of human glioblastoma cells via $\mathrm{AP}-1$ and $\mathrm{NF \kappa B}$ transcription factors. Journal of neurochemistry, 102(2), 522-538.

Ding, Y., Cao, Z., Cao, L., Ding, G., Wang, Z., \& Xiao, W. (2017). Antiviral activity of chlorogenic acid against influenza A (H1N1/H3N2) virus and its inhibition of neuraminidase. Scientific reports, 7, 45723 .

Ding, Y., Chen, L., Wu, W., Yang, J., Yang, Z., \& Liu, S. (2017). Andrographolide inhibits influenza a virus-induced inflammation in a murine model through NF- $\mathrm{kB}$ and JAK-STAT signaling pathway. Microbes and infection, 19(12), 605-615.

Duan, Y., Zhu, H.-L., \& Zhou, C. (2020). Advance of promising targets and agents against 2019nCoV in China. Drug Discovery Today.

Elfiky, A. A. (2020). Anti-HCV, nucleotide inhibitors, repurposing against COVID-19. Life sciences, 117477.

Eskandarian, R., Sani, Z. A., Behjati, M., Zahmatkesh, M., Haddadi, A., Kakhi, K., . . Hussain, S. (2021). Identification of clinical features associated with mortality in COVID-19 patients. medRxiv.

Fehr, A. R., \& Perlman, S. (2015). Coronaviruses: an overview of their replication and pathogenesis. In Coronaviruses (pp. 1-23): Springer.

Fei, Q., LIANG, Z.-x., SHE, D.-y., Guang-Tao, Y., \& CHEN, L.-a. (2011). A Clinical Study on the Effects and Mechanism of Xuebijing Injection () in Severe Pneumonia Patients. Journal of Traditional Chinese Medicine, 31(1), 46-49.

Fenwick, G. R., Hanley, A. B., \& Whitaker, J. R. (1985). The genus Allium—part 1. Critical Reviews in Food Science \& Nutrition, 22(3), 199-271.

Ge, H., Wang, Y.-F., Xu, J., Gu, Q., Liu, H.-B., Xiao, P.-G., . . S Su, H. (2010). Anti-influenza agents from traditional Chinese medicine. Natural product reports, 27(12), 1758-1780.

Ghassemi, N., Shoeibi, A., Khodatars, M., Heras, J., Rahimi, A., Zare, A., . . Gorriz, J. M. (2021). Automatic Diagnosis of COVID-19 from CT Images using CycleGAN and Transfer Learning. arXiv preprint arXiv:2104.11949.

Gorbalenya, A. E. (2020). Severe acute respiratory syndrome-related coronavirus-The species and its viruses, a statement of the Coronavirus Study Group. BioRxiv.

Graham, D. Y., Anderson, S.-Y., \& Lang, T. (1999). Garlic or jalapeno peppers for treatment of Helicobacter pylori infection. The American journal of gastroenterology, 94(5), 1200-1202.

Guan, S.-P., Kong, L.-R., Cheng, C., Lim, J. C., \& Wong, W. F. (2011). Protective role of 14-deoxy11, 12-didehydroandrographolide, a noncytotoxic analogue of andrographolide, in allergic airway inflammation. Journal of natural products, 74(6), 1484-1490.

Guo, Y.-R., Cao, Q.-D., Hong, Z.-S., Tan, Y.-Y., Chen, S.-D., Jin, H.-J., . . Y Yan, Y. (2020). The origin, transmission and clinical therapies on coronavirus disease 2019 (COVID-19) outbreak-an update on the status. Military Medical Research, 7(1), 1-10.

He, J., Tan, Z., Zhang, M., \& Guo, L. (2015). Effect of Xuebijing injection on hemodynamics and endothelial function in patients with severe sepsis: a prospective study. Zhonghua wei zhong bing ji jiu yi xue, 27(2), 127-132.

Henning, S. M., Aronson, W., Niu, Y., Conde, F., Lee, N. H., Seeram, N. P., . . Moro, A. (2006). Tea polyphenols and theaflavins are present in prostate tissue of humans and mice after green and black tea consumption. The Journal of nutrition, 136(7), 1839-1843.

Huang, C., Wang, Y., Li, X., Ren, L., Zhao, J., Hu, Y., . . Gu, X. (2020). Clinical features of patients infected with 2019 novel coronavirus in Wuhan, China. The Lancet, 395(10223), 497-506.

Ibrahim, M. Y., Hashim, N. M., Mariod, A. A., Mohan, S., Abdulla, M. A., Abdelwahab, S. I., \& Arbab, I. A. (2016). $\alpha$-Mangostin from Garcinia mangostana Linn: an updated review of its pharmacological properties. Arabian journal of Chemistry, 9(3), 317-329.

Iizuka, S., Ishige, A., Komatsu, Y., Matsumiya, T., Tsuji, M., \& Takeda, H. (1998). Effects of Saikoka-ryukotsu-borei-to on irritable characteristics in El mice. Methods and findings in experimental and clinical pharmacology, 20, 19-26.

Jiang, M., Zhou, M., Han, Y., Xing, L., Zhao, H., Dong, L., . . Luo, G. (2013). Identification of NF$\kappa \mathrm{B}$ Inhibitors in Xuebijing injection for sepsis treatment based on bioactivity-integrated UPLC-Q/TOF. Journal of ethnopharmacology, 147(2), 426-433. 
Khozeimeh, F., Sharifrazi, D., Izadi, N. H., Joloudari, J. H., Shoeibi, A., Alizadehsani, R., . . . Moosaei, H. (2021). CNN AE: Convolution Neural Network combined with Autoencoder approach to detect survival chance of COVID 19 patients. arXiv preprint arXiv:2104.08954.

Kou, W., Sun, R., Wei, P., Yao, H.-B., Zhang, C., Tang, X.-Y., \& Hong, S.-L. (2014). Andrographolide suppresses IL-6/Stat3 signaling in peripheral blood mononuclear cells from patients with chronic rhinosinusitis with nasal polyps. Inflammation, 37(5), 1738-1743.

Kuster, G. M., Pfister, O., Burkard, T., Zhou, Q., Twerenbold, R., Haaf, P., . . Osswald, S. (2020). SARS-CoV2: should inhibitors of the renin-angiotensin system be withdrawn in patients with COVID-19? European Heart Journal.

Lai, C.-C., Wang, C.-Y., Wang, Y.-H., Hsueh, S.-C., Ko, W.-C., \& Hsueh, P.-R. (2020). Global epidemiology of coronavirus disease 2019: disease incidence, daily cumulative index, mortality, and their association with country healthcare resources and economic status. International Journal of Antimicrobial Agents, 105946.

Lee, S. K., Park, Y. J., Ko, M. J., Wang, Z., Lee, H. Y., Choi, Y. W., \& Bae, Y.-S. (2015). A novel natural compound from garlic (Allium sativum L.) with therapeutic effects against experimental polymicrobial sepsis. Biochemical and biophysical research communications, 464(3), 774-779.

Li, C., Yang, Y., \& Ren, L. (2020). Genetic evolution analysis of 2019 novel coronavirus and coronavirus from other species. Infection, Genetics and Evolution, 104285.

Li, H.-B., \& Chen, F. (2005). Preparative isolation and purification of phillyrin from the medicinal plant Forsythia suspensa by high-speed counter-current chromatography. Journal of Chromatography A, 1083(1-2), 102-105.

Li, P., Tian, W., \& Ma, X. (2014). Alpha-mangostin inhibits intracellular fatty acid synthase and induces apoptosis in breast cancer cells. Molecular cancer, 13(1), 138.

Li, W.-j., Wang, J.-f., \& Wang, X.-p. (2013). Wilson's disease: Update on integrated chinese and western medicine. Chinese journal of integrative medicine, 19(3), 233-240.

Lin, C.-W., Tsai, F.-J., Tsai, C.-H., Lai, C.-C., Wan, L., Ho, T.-Y., . . Chao, P.-D. L. (2005). AntiSARS coronavirus $3 \mathrm{C}$-like protease effects of Isatis indigotica root and plant-derived phenolic compounds. Antiviral research, 68(1), 36-42.

Lloyd-Sherlock, P., Ebrahim, S., Geffen, L., \& McKee, M. (2020). Bearing the brunt of covid-19: older people in low and middle income countries. In: British Medical Journal Publishing Group.

LU, Y.-q., GU, L.-h., \& Huang, W.-d. (2010). Effect of Xuebijing injection on peripheral Tlymphocyte subpopulations in patients with severe trauma. Chinese Journal of Traumatology (English Edition), 13(2), 72-76.

Ma, Q., Huang, W., Zhao, J., \& Yang, Z. (2020). Liu Shen Wan inhibits influenza a virus and excessive virus-induced inflammatory response via suppression of TLR4/NF- $\mathrm{kB}$ signaling pathway in vitro and in vivo. Journal of ethnopharmacology, 252, 112584.

Mathew, D., \& Hsu, W.-L. (2018). Antiviral potential of curcumin. Journal of functional foods, 40, 692-699.

Matsukura, S., Kokubu, F., Kubo, H., Tomita, T., Tokunaga, H., Kadokura, M., . . Suzaki, H. (1998). Expression of RANTES by normal airway epithelial cells after influenza virus A infection. American Journal of Respiratory Cell and Molecular Biology, 18(2), 255-264.

Mehta, P., McAuley, D. F., Brown, M., Sanchez, E., Tattersall, R. S., \& Manson, J. J. (2020). COVID-19: consider cytokine storm syndromes and immunosuppression. The Lancet.

Menon, V. P., \& Sudheer, A. R. (2007). Antioxidant and anti-inflammatory properties of curcumin. In The molecular targets and therapeutic uses of curcumin in health and disease (pp. 105-125): Springer.

Milner, J. (2001). A historical perspective on garlic and cancer. The Journal of nutrition, 131(3), 1027S-1031S.

Mishra, S., \& Palanivelu, K. (2008). The effect of curcumin (turmeric) on Alzheimer's disease: An overview. Annals of Indian Academy of Neurology, 11(1), 13.

Nie, X., Chen, S.-R., Wang, K., Peng, Y., Wang, Y.-T., Wang, D., . . . Zhou, G.-C. (2017). Attenuation of innate immunity by andrographolide derivatives through NF-kB signaling pathway. Scientific reports, 7(1), 1-10. 
Organization, W. H. (2020). Coronavirus disease (COVID-2019) situation reports. Available on: https://www. WHO. Int/docs/default-source/coronaviruse/situation-reports/20200221-sitrep32-covid-19.

Piao, X.-L., Jang, M. H., Cui, J., \& Piao, X. (2008). Lignans from the fruits of Forsythia suspensa. Bioorganic \& medicinal chemistry letters, 18(6), 1980-1984.

Piper, J. T., Singhal, S. S., Salameh, M. S., Torman, R. T., Awasthi, Y. C., \& Awasthi, S. (1998). Mechanisms of anticarcinogenic properties of curcumin: the effect of curcumin on glutathione linked detoxification enzymes in rat liver. The international journal of biochemistry \& cell biology, 30(4), 445-456.

Pozzolini, M., Scarfî, S., Benatti, U., \& Giovine, M. (2003). Interference in MTT cell viability assay in activated macrophage cell line. Analytical biochemistry, 2(313), 338-341.

Prompetchara, E., Ketloy, C., \& Palaga, T. (2020). Immune responses in COVID-19 and potential vaccines: Lessons learned from SARS and MERS epidemic. Asian Pac J Allergy Immunol.

Qi, Y., \& Ren, Y. (2009). The progress of the lingnan area of traditional Chinese herbs: roots of Ilex asprella. Asia-Pacific Trad Med (Chin), 5, 29-32.

Qian, Y., Sun, J., Wang, Z., \& Yang, J. (2006). Shen-Fu attenuates endotoxin-induced acute lung injury in rats. The American journal of Chinese medicine, 34(04), 613-621.

Qu, H., Zhang, Y., Wang, Y., Li, B., \& Sun, W. (2008). Antioxidant and antibacterial activity of two compounds (forsythiaside and forsythin) isolated from Forsythia suspensa. Journal of Pharmacy and Pharmacology, 60(2), 261-266.

Qu, X.-y., Li, Q.-j., Zhang, H.-m., Zhang, X.-j., Shi, P.-h., Zhang, X.-j., . . . Wang, S.-q. (2016). Protective effects of phillyrin against influenza A virus in vivo. Archives of pharmacal research, 39(7), 998-1005.

Robert, E. (1957). The Phenolic Substances of Manufactured Tea. J. Sci. Food Agric, 2, 72-80.

Sharifrazi, D., Alizadehsani, R., Roshanzamir, M., Joloudari, J. H., Shoeibi, A., Jafari, M., . . . Acharya, U. R. (2021). Fusion of convolution neural network, support vector machine and Sobel filter for accurate detection of COVID-19 patients using X-ray images. Biomedical Signal Processing and Control, 68, 102622. doi:https://doi.org/10.1016/j.bspc.2021.102622

Shi, H., Hong, Y., Qian, J., Cai, X., \& Chen, S. (2017). Xuebijing in the treatment of patients with sepsis. The American journal of emergency medicine, 35(2), 285-291.

Shoeibi, A., Khodatars, M., Alizadehsani, R., Ghassemi, N., Jafari, M., Moridian, P., . . Zare, A. (2020). Automated detection and forecasting of covid-19 using deep learning techniques: A review. arXiv preprint arXiv:2007.10785.

Sordillo, P. P., \& Helson, L. (2015). Curcumin suppression of cytokine release and cytokine storm. A potential therapy for patients with Ebola and other severe viral infections. in vivo, 29(1), 1-4.

Tarasuk, M., Songprakhon, P., Chimma, P., Sratongno, P., Na-Bangchang, K., \& Yenchitsomanus, P.t. (2017). Alpha-mangostin inhibits both dengue virus production and cytokine/chemokine expression. Virus research, 240, 180-189.

Thevarajan, I., Nguyen, T. H., Koutsakos, M., Druce, J., Caly, L., van de Sandt, C. E., . . Cowie, B. (2020). Breadth of concomitant immune responses prior to patient recovery: a case report of non-severe COVID-19. Nature Medicine, 1-3.

Ushiroyama, T., Ikeda, A., Sakuma, K., \& Ueki, M. (2005). Chai-hu-gui-zhi-gan-jiang-tang regulates plasma interleukin-6 and soluble interleukin-6 receptor concentrations and improves depressed mood in climacteric women with insomnia. The American journal of Chinese medicine, 33(05), 703-711.

Vankadari, N., \& Wilce, J. A. (2020). Emerging WuHan (COVID-19) coronavirus: glycan shield and structure prediction of spike glycoprotein and its interaction with human CD26. Emerging Microbes \& Infections, 9(1), 601-604.

Wang, J.-X., Zhou, J.-Y., Yang, Q.-W., Chen, Y., Li, X., Piao, Y.-A., \& Li, H.-Y. (2008). An improved embryonated chicken egg model for the evaluation of antiviral drugs against influenza A virus. Journal of virological methods, 153(2), 218-222.

Wu, X., Chung, V. C., Lu, P., Poon, S. K., Hui, E. P., Lau, A. Y., . . Wu, J. C. (2016). Chinese herbal medicine for improving quality of life among nonsmall cell lung cancer patients: overview of systematic reviews and network meta-analysis. Medicine, 95(1). 
Xu, X., Han, M., Li, T., Sun, W., Wang, D., Fu, B., . . Li, X. (2020). Effective treatment of severe COVID-19 patients with tocilizumab. ChinaXiv, 202003(00026), v1.

Xu, Y., \& Liu, L. (2017). Curcumin alleviates macrophage activation and lung inflammation induced by influenza virus infection through inhibiting the NF- $\mathrm{KB}$ signaling pathway. Influenza and other respiratory viruses, 11(5), 457-463.

Yao, X., Li, T., He, Z., Ping, Y., Liu, H., Yu, S., . . Fu, W. (2020). A pathological report of three COVID-19 cases by minimally invasive autopsies. Zhonghua bing li xue za zhi=Chinese journal of pathology, 49, E009.

Yarnell, E. (2018). Herbs for Viral Respiratory Infections. Alternative and Complementary Therapies, 24(1), 35-43.

Zhang, C., Wu, Z., Li, J.-W., Zhao, H., \& Wang, G.-Q. (2020). The cytokine release syndrome (CRS) of severe COVID-19 and Interleukin-6 receptor (IL-6R) antagonist Tocilizumab may be the key to reduce the mortality. International Journal of Antimicrobial Agents, 105954.

Zhang, F., Lu, S., Jin, S., Chen, K., Li, J., Huang, B., \& Cao, Y. (2018). Lidanpaidu prescription alleviates lipopolysaccharide-induced acute kidney injury by suppressing the NF-kB signaling pathway. Biomedicine \& Pharmacotherapy, 99, 245-252.

Zhang, T., He, Y., Xu, W., Ma, A., Yang, Y., \& Xu, K.-F. (2020). Clinical trials for the treatment of Coronavirus disease 2019 (COVID-19): A rapid response to urgent need. Science China Life Sciences, 1-3.

Zhang, Y., Jiang, X., Peng, K., Chen, C., Fu, L., Wang, Z., . . . Liang, G. (2014). Discovery and evaluation of novel anti-inflammatory derivatives of natural bioactive curcumin. Drug design, development and therapy, 8, 2161.

Zhong, W.-t., Wu, Y.-c., Xie, X.-X., Zhou, X., Wei, M.-m., Soromou, L.-W., . . Wang, D.-c. (2013). Phillyrin attenuates LPS-induced pulmonary inflammation via suppression of MAPK and NF$\kappa \mathrm{B}$ activation in acute lung injury mice. Fitoterapia, 90, 132-139.

Zhu, H.-y., Huang, H., Shi, X.-1., Zhou, W., Zhou, P., Yan, Q.-1., . . . Ju, D.-w. (2015). Qiangzhi Decoction (姜跖汤) protects mice from influenza A pneumonia through inhibition of inflammatory cytokine storm. Chinese journal of integrative medicine, 21(5), 376-383.

Zorofchian Moghadamtousi, S., Abdul Kadir, H., Hassandarvish, P., Tajik, H., Abubakar, S., \& Zandi, K. (2014). A review on antibacterial, antiviral, and antifungal activity of curcumin. BioMed research international, 2014.

Zu, M., Yang, F., Zhou, W., Liu, A., Du, G., \& Zheng, L. (2012). In vitro anti-influenza virus and anti-inflammatory activities of theaflavin derivatives. Antiviral research, 94(3), 217-224. 